\title{
CHORWACJA I WĘGRY W KRONICE WĘGIERSKO-POLSKIEJ
}

\author{
RYSZARD GRZESIK
}

\begin{abstract}
Croatia and Hungary in the Hungarian-Polish Chronicle.
In the Hungarian-Polish Chronicle, written at the turn of the 1230s, one can find a piece of information on Croatia. It is a note on St Paul's mission in Split, where he allegedly was a Bishop before his travel to Rome, where he found his martyrdom and a story of a Croatian ruler, who was killed by his subjects. The first story used a motif, which was probably popular in medieval Dalmatia, that St Paul was a real apostle of that region. It was Constantin Porphyrogenitus who noted his presence in the context of Adriatic islands and Thomas, archdeacon of Split (Spalato) who argued against this idea. The another story could reflect a tradition of a death of a Great-Moravian ruler, which was mythologized and deprived of a spatial and temporal context. It is interesting that the Hungarians' raid to their new homeland was presented else as in another sources and in the reality: not from the north-east (Ruthenian territories), but from south (Slavonia). The northern part of Slavonia was nominated Hungary according to the Chronicle, which reflected the geographical and economical unity of Hungarian medieval Kingdom.
\end{abstract}

STRESZCZENIE. Chorwacja i Wegry w Kronice wegiersko-polskiej.

W Kronice węgiersko-polskiej, napisanej na przełomie lat 20. i 30. XIII w., można znaleźć informacje o Chorwacji. Odnotowano misję św. Pawła w Splicie, gdzie miał być biskupem przed swoją podróżą do Rzymu, gdzie znalazł śmierć męczeńską oraz zamieszczono opowiadanie o władcy chorwackim zabitym przez swoich poddanych. Pierwsze z powyższych opowiadań wykorzystuje motyw chyba popularny w średniowiecznej Dalmacji, że św. Paweł był rzeczywistym apostołem w tej krainie. Już Konstantyn Porfirogeneta wspomniał o obecności Apostoła w kontekście wysp adriatyckich, zaś Tomasz ze Splitu jawnie polemizował z tym przekonaniem. Drugie opowiadanie może odzwierciedlać tradycję o śmierci wielkomorawskiego władcy, która została zmitologizowana i pozbawiona kontekstu czasoprzestrzennego. Co ciekawe, węgierska droga do nowej ojczyzny została przedstawiona inaczej, niż w innych źródłach i w rzeczywistości. Węgrzy mieli przybyć nie z północnego wschodu, z ziem ruskich, lecz z południa, ze Sławonii. Północna część Sławonii miała zostać przemianowana na Węgry, co zdaje się odzwierciedlać przekonanie o geograficznej i gospodarczej jedności średniowiecznej monarchii węgierskiej.

Autor: Ryszard Grzesik, Zakład Historii Instytutu Slawistyki PAN, ul. Błękitna 1/7, 60-656 Poznań, e-mail: grzesik@man.poznan.pl; ORCID iD: https://orcid.org/0000-0001-7887-6895.

Keywords: Croatia, Dalmatia, Hungary, Attila, Slavonia, Hungarian-Slavic relationship.

Słowa kluczowe: Chorwacja, Dalmacja, Węgry, Attyla, Sławonia, stosunki węgiersko-słowiańskie.

Balcanica Posnaniensia. Acta et studia, XXVI, Poznań 2019, Wydawnictwo Instytutu Historii UAM, pp. 73-81, ISBN 978-83-66355-32-3, ISSN 0239-4278. Polish text with summaries in English and Polish.

doi.org/10.14746/bp.2019.26.4 
Kronika węgiersko-polska, łącząca w sobie wiadomości węgierskie i polskie, pochodząca z pierwszych dziesięcioleci XIII w., zaczyna się od utrzymanego w nieco baśniowym tonie opowiadania o czynach króla Akwili/Attyli. Szukając rycerskiej sławy ruszył on ze swej dawnej ojczyzny we Wschodnich Węgrzech i przemierzał Europę pokonując liczne ludy i zdobywając miasta. Zamierzał zdobyć Rzym, ale wtedy w wizji anioł przykazał mu, „abyś w zapalczywości swojej nie wkraczał do świętego miasta Rzymu, gdzie spoczywają ciała moich apostołów, ani byś się nie ośmielił porwać na to, lecz abyś zawrócił i pomścił wybranego przeze Mnie króla Kazimierza - który w Sławonii i Chorwacji z całego serca i zapału umysłu wiernie służył Mi w sprawach świeckich - na tych, którzy zdradziecko i haniebnie go zabili, ponieważ powiedzieli: żaden król nigdy nie będzie [panował] nad nami, lecz sami będziemy się rządzić"1. Król zatem udał się w stronę Wenecji, założył przy okazji Akwileę nazwaną tak na cześć swego imienia, „stąd ruszył się ze swoimi wojskami, przeszedł Alpy Karynckie i dotarł do granic Chorwacji-Sławonii, między rzekami Sawą a Drawą, tam wystąpili przeciwko niemu książęta Chorwacji i Sławonii”"2, którzy zostali oczywiście pokonani. I dalej czytamy: „Gdy przeto [król] po zwycięstwie przeszedł rzekę, która zwie się Drawą, i zobaczył ziemię płaską i urodzajną, a później obliczył, że od wyjścia z ich ziemi, Wschodnich Węgier, minęło 25 lat... zaczął się zastanawiać, co powinien uczynić: czy wrócić do własnej ziemi, czy posiąść tę zajętą. (...) Przechodził więc tę ziemię i napawał się nią, gdyż była to ziemia obiecana, tak jak ziemia dla ludu izraelskiego. Posławszy przeto swoich posłów otrzymał od księcia Słowian córkę tegoż pokolenia i wziął ją sobie za żonę, podobnie i wojsko jego brało żony z tegoż pokolenia; przeszedłszy zaś Dunaj znalazł ziemię płaską i równinną, zieleniącą się obfitymi trawami, pełną pasterzy i bydła, jak i dzikich klaczy i udomowionych źrebiąt. Na ziemi tej przebywali bowiem tylko pasterze i rolnicy. Król zaś Sławonii i Chorwacji nadmorskiej upodobał sobie miasto, które zwie się Splitem, które święty Paweł apostoł nawrócił na wiarę chrześcijańską i przez pięć lat dzierżył tamtejszą katedrę, a potem po wyświęceniu biskupa udał się do Rzymu. Potem zaś [Akwila] wyruszył i przeszedł rzekę, którą zwą Cisą, i tam znalazł ziemię jeszcze bardziej równinną i przestronną, która bardzo mu się zaczęła podobać. Wtedy, przywoławszy całe swoje wojsko, nazwał ją Węgrami na cześć i chwałę swojego wojska"3. Możemy dodać jeszcze, że rozdzielił między swych baronów tę ziemię oraz ustanowił zasady następstwa tronu.

Słowa Kroniki węgiersko-polskiej kierują naszą uwagę na dwa zagadnienia. Pierwszym z nich jest motyw Chorwacji i Sławonii, w którym wyróżnić można opowiadanie o zabójstwie miejscowego władcy pomszczonego później przez Węgrów oraz o św. Pawle jako założycielu i pierwszym biskupie Kościoła splickiego, nato-

${ }^{1}$ Żywot św. Stefana króla Węgier czyli Kronika węgiersko-polska, thum. R. Grzesik, Warszawa 2003, s. 56-57.

2 Żywot, s. 58-59.

${ }^{3}$ Żywot, s. 60-61. 
miast drugim to charakterystyka terenów między Dunajem, Cisą i na wschód od Cisy jako Ziemi Obiecanej dla przybyszów. Przypatrzmy się poszczególnym wątkom.

Zacznijmy rozważania od św. Pawła. W swoich wędrówkach wielokrotnie zahaczał o Bałkany, niosąc Słowo Boże w Grecji i Macedonii. Wiemy, że po aresztowaniu wieziony był do Rzymu przed oblicze cesarskie. Sztorm miotał statkiem po Adriatyku (in Hadria; Dz. 27,27), wreszcie wyrzucił rozbitków na wyspę zwaną Melita (Dz. 28,1). Dzisiaj wiemy, że chodzi o Maltę ${ }^{4}$. Jednak wzmianka o Adriatyku w tym kontekście musiała wzbudzić wątpliwości interpretacyjne. Konstantyn Porfirogeneta wymieniając wyspy dalmatyńskiej Paganii wspomina najpierw o wielkiej wyspie o nazwie Kurkra lub Kiker, a następnie zauważa; ,inna wielka wyspa Meleta lub Malozeatai, o której wspomina w Dziejach Apostolskich święty Łukasz nazywając ją Melita; na niej mianowicie żmija ukąsiła świętego Pawła w palec, a on spalił ją w ogniu"5. Wincenty Swoboda zauważa, że pierwszą z tych wysp jest dzisiejsza Korczula, zaś drugą, na której miał przebywać św. Paweł, Mljet ${ }^{6}$. A zatem w czasach uczonego cesarza musiała już istnieć tradycja o pobycie św. Pawła w Dalmacji ${ }^{7}$. Utrzymywała się ona na pewno w XIII w., jak przekonuje jawna polemika z nią podjęta przez Tomasza, arcydiakona splickiego, żyjącego w latach 1200-1201 do 8 maja 1268 r., w kronice napisanej pod koniec jego życia ${ }^{8}$. Mianowicie Tomasz tak pisze w kontekście początków Kościoła splickiego: „Zatem pierwszy był św. Paweł apostoł, który rozkrzewiał ewangelię Chrystusową od Jerozolimy aż po Illiricum; on sam jednak nie nawiedził Illiricum, by nauczać, lecz posłał swego ucznia Tytusa, jak rzekł do Tymoteusza: Krescens podążył do Galacji, Tytus do Dalmacji”9. Lecz w końcu na

${ }^{4}$ Por. np. Pismo Święte Stary i Nowy Testament w przekładzie z języków oryginalnych, oprac. zespół pod red. ks. M. Petera i ks. M. Wolniewicza, Poznań 2006, s. 1591 i przyp. do ks. 28, rozdz. 1-10.

${ }^{5}$ Testimonia najdawniejszych dziejów Słowian, seria grecka, z. 3: Pisarze z VII-X wieku, wyd.

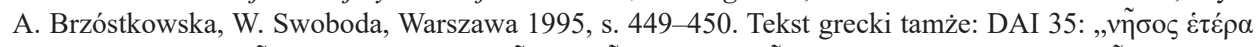

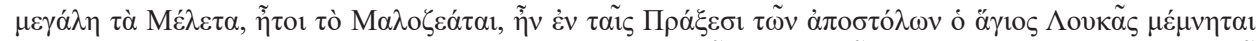

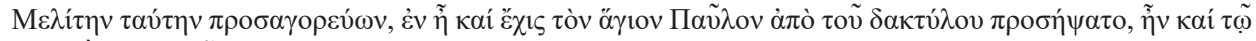

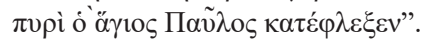

6 Testimonia, s. 473 przyp. 67.

${ }^{7}$ Podkreśla to zresztą W. Swoboda, op. cit.: „,Możliwe jednak, iż wzmianka ta u Konstantyna jest odbiciem jakiejś lokalnej tradycji”.

${ }^{8} \mathrm{O}$ autorze i jego dziele zob. N. Klaić, Povijest Hrvata u ranom srednjem vijeku, Zagreb 1971, s. 2226; M. Kurelac, Toma arhiđakon (Thomas archidiaconus Spalatensis, Toma Splićanin), w: Enciklopedija Jugoslavije, t. 8, Zagreb 1971, s. 348-349; L. Veszprémy, Thomas of Split, w: Encyclopedia of the Medieval Chronicle, wyd. G. Dunphy, Leiden - Boston 2010, t. 2, s. 1427-1428 oraz wydanie cyt. w następnym przypisie.

${ }^{9}$ Thomae archidiaconi Spalatensis Historia Salonitanorum atque Spalatinorum pontificum. Archdeacon Thomas of Split, History of the Bishops of Salona and Split, ed. by O. Perić, D. Karbić, M. Matijević Sokol and J. Ross Sweeney, Budapest - New York 2006, rozdz. 3, s. 12: "Primus itaque beatus Paulus apostolus qui ab Ierusalem usque Illyricum replevit evangelio Christi; non tamen ipse per se intravit Illyricum predicare, sed misit Titum discipulum suum, sicut dicit ad Timoteum: Crescens abiit in Galatiam, Titus in Dalmatiam”. Por. 2 Tm. 4,10. Polski przekład zob. Żywot św. Stefana, s. 61 przyp. 41. O Tomaszu zob Wstęp do edycji, s. XXII-XXIX. 
mocy testamentu Apostoła Tytus skierowany został na Kretę, a św. Piotr na jego miejsce skierował Syryjczyka Domniusa, który został w końcu biskupem Salony ${ }^{10}$.

Jak się wydaje, Kronika węgiersko-polska zapisała żywą w Dalmacji tradycję o misyjnej i organizacyjnej działalności św. Pawła tamże. Nie była to jednak jedyna tradycja związana z Chorwacją. Jak pamiętamy, pojawił się w jej narracji motyw pomsty zabitego i umiłowanego przez Boga władcy Chorwacji i Sławonii. Jak wiemy, dłuższa redakcja Kroniki podaje jego imię w wersji: Kazimierz. Jednak lectio difficilior przekazuje redakcja krótsza, w której zapisano trezimir, co przy identycznym zapisie liter 't' oraz 'c' czytać należałoby Crezimir. W tej formie bez trudu odnajdujemy popularne imię chorwackich władców: Krešimir ${ }^{11}$. Imię to pod piórem polskich pisarzy łatwo zmieniło się w Kazimierza - popularne imię z kolei polskich władców.

Opowiadanie o zabitym władcy kieruje naszą uwagę na kolejną kronikę południowosłowiańską, pochodzący z drugiej połowy XII w. tzw. Latopis popa Duklanina. Nas jednak interesować będzie nie łaciński oryginał, lecz chorwacki przekład pochodzący chyba z XIV w., w którym dodano historię zabicia przez poddanych dobrego króla Zwonimira, gdyż wbrew woli poddanych chciał iść na wyprawę krzyżową. Kara za zbrodnię była straszna, bo Chorwatom odebrano władcę wywodzącego się z ich pokolenia i języka. Na trwale zostali poddani pod władzę cudzych, bo węgierskich władców $^{12}$. Od początku mojego zainteresowania tą problematyką widziałem w opowiadaniu Kroniki węgiersko-polskiej świadectwo kształtującej się tradycji, którą później powiązano ze Zwonimirem, mającej wyjaśnić, dlaczego Chorwacją nie włada rodzima dynastia, a kraj jest częścią Królestwa Węgier. Tę interpretację, bez znajomości zresztą moich wniosków, poparł niedawno w znakomitym artykule Dražen Nemet ${ }^{13}$.

Jak jednak mogła zrodzić się ta tradycja. Tu, jak mi się wydaje, właściwej odpowiedzi udziela Martin Homza, od lat analizujący tradycję wielkomorawską, szczególnie jej polityczny aspekt związany z postacią króla Świętopełka. Sądzi on, że prawdopodobnie tradycja ta przechowywała pamięć o realnych wydarzeniach, które doprowadziły do upadku wielkomorawskiej państwowości. Jej znajomość w Chorwacji nie by-

10 Thomae... Historia, s. 12-14.

11 B. Kürbisówna, Studia nad Kronika wielkopolska, Poznań 1952, s. 140-141. Szerzej przebieg dyskusji zob. R. Grzesik, Kronika węgiersko-polska. Z dziejów polsko-węgierskich kontaktów kulturalnych wśredniowieczu, Poznań 1999, s. 82-85.

${ }^{12}$ Historia Królestwa Stowian czyli Latopis Popa Duklanina, wyd. J. Leśny, Warszawa 1988, s. 6. Niestety, polskie tłumaczenie dokonane przez nieodżałowanego Jana Leśnego nie zawiera redakcji chorwackiej. Ljetopis Popa Dukljanina, [wyd. V. Mošin], Zagreb 1950, rozdz. XXVII, s. 66-68. Swoją drogą treść można analizować pod kątem antysemityzmu, gdyż zabójcy władcy porównywani są do Żydów mordujących Jezusa. Widać, jak niechlubne wzory myślenia trwają przez wieki w naszej, europejskiej świadomości.

${ }^{13}$ R. Grzesik, Kronika, s. 86-90; tegoż, Sources of a Story About the Murdered Croatian King in the Hungarian-Polish Chronicle, „Povijesni Prilozi”, R. 22, 2003, t. 24, s. 97-104; D. Nemet, Smrt hrvatskog kralja Zvonimira - problem, izvori i tumačenja, „Radovi Zavoda za hrvatsku povijest u Zagrebu”, t. 38, 2006, s. 73-91 (w Internecie: http://www.ffzg.unizg.hr/pov/pov2/files/3zavod/radovi38/nemet38.pdf [dostęp 22 marca 2019 r.]. 
łaby niczym dziwnym, jeśli pamiętamy, że m.in. do tego kraju uciekło wielu uczniów św. św. Konstantyna-Cyryla i Metodego wygnanych z Moraw po śmierci Metodego przez Świętopełka. Klasztory reguły benedyktyńskiej stosujące w liturgii język starocerkiewnosłowiański trwały w tym kraju mimo ciągle ponawianych ograniczeń i zakazów, a po legalizacji tej liturgii przez papieża Innocentego IV w 1248 r. mogły już legalnie rozkwitać, a tradycja cyrylometodiańska i alfabet głagolicki do dziś są wyróżnikiem chorwackiej odrębności ${ }^{14}$. Zatem pierwotnie mogły to być opowiadania o zabiciu bliżej nieokreślonego władcy, za którymi stały realne wydarzenia z przełomu IX i X w., zaszłe na terenie Wielkich Moraw. Przechowałyby się one w którymś z klasztorów liturgii słowiańskiej i w wersji zmitologizowanej, oderwanej od swojego miejsca i czasu, jako wątek wędrowny, znalazłyby nowe zakorzenienie na gruncie chorwackiej tradycji historycznej, dodajmy, żywe w niej aż po dziś dzień.

Jednak w swojej refleksji nad Kronika węgiersko-polska Martin Homza idzie jeszcze dalej. Zastanawiając się nad terminem Kroniki „Sclavonia” uznał, że określa on całe Węgry, na które został przeniesiony z Wielkich Moraw, które zatem również nazywane były Sławonią. Komentując moje poglądy stwierdza, jakobym ,pod tlakom mad'arskej historiografie bál [sa] naplno povedat', že „Sclavonia” Uhorsko-pol'skej kroniky rovná sa historické Uhorsko"15. Na zarzut ten mogę odpowiedzieć, że na mnie wpływała nie historiografia węgierska, ale odczyt źródła, gdzie termin "Sclavonia" jest wyraźnie odniesiony geograficznie do krainy na wschód od Alp, leżącej inter fluuios Savam et Dravam ${ }^{16}$. Pokrywa się to z pojęciem Sławonii funkcjonującym od średniowiecza aż po dziś ${ }^{17}$. Oczywiście już we wstępie do Kroniki termin ten użyty jest w szerszym znaczeniu, czyli tak jak chce Martin Homza i określa chyba całe Węgry ${ }^{18}$. Nie doszukiwałbym się tu jednak przeniesienia nazwy z Moraw, któ-

14 M. Homza, Uhorsko-pol'ská kronika. Nedocenený prameň k dejinám strednej Európy, Bratislava 2009, s. 54-55; M. Homza et al., Svätopluk v európskom písomníctve. Štúdie z dejín svätoplukovskej legendy, Bratislava 2013, s. 58. Cenne są jego uwagi, że część wiadomości o Świętopełku, np. długość jego panowania przechowały się w Latopisie popa Duklanina, tamże, s. 58, 125-140. Por też I. Panic, Ostatnie lata Wielkich Moraw, Katowice 2000, s. 155-156, 164-165; R. Grzesik, Great Moravia as the Basis of the Central European Medieval Historical Tradition, w: Slovensko a Chorvátsko. Historické paralely a vzt'ahy (do roku 1780). Slovaćka i Hrvatska. Povijesne paralele i veze (do godine 1780.), wyd. M. Homza, J. Lukačka, N. Budak, Bratislava 2013, s. 66-71 oraz tegoż, Hungaria-Slavia-Europa Centralis. Studia z dziejów kultury środkowoeuropejskiej we wczesnym średniowieczu, Warszawa 2014, s. 63-64.

${ }^{15}$ M. Homza, Pokus o interpretáciu úlohy kňažnej Adelajdy v Uhorsko-pol’skej kronike, „Historický časopis”, t. 47, 1999, z. 3, s. 367 przyp. 73 oraz moja recenzja w Studiach Źródłoznawczych, t. 38, 2000, s. 126.

16 Chronica Hungaro-Polonica, pars 1. (Textus cum varietate lectionum), ed. B. Karácsonyi, Szeged 1969 (Acta Historica Universitatis Szegedensis de Attila József nominatae, t. 26) [dalej cyt.: Chron.], s. 17; Żywot, s. 59.

17 T. Bali, Slavonski Meandar. Prostor i pojam Slavonije u XIII. stoljeću, Zagreb 2014 utożsamia Sławonię z terenami średniowiecznego biskupstwa zagrzebskiego.

18 Węgrzy ochrzczeni zostali ,,in aliena [regione], que sclauonia nominatur”, Chron., s. 14. W szerszym znaczeniu występuje też w informacji, że Akwila zajęte tereny Sławonii na północ od Drawy nazwał Węgrami, Chron, s. 19. 
re przecież w źródłach funkcjonują jako Morawy, a nie Słowiańszczyzna. To raczej pamięć o Słowianach panońskich zamieszkujących tereny niegdysiejszej starożytnej Panonii, żywa jeszcze w czasie powstawania Kroniki przyczyniła się do rozszerzania tej nazwy na tereny całego Królestwa.

Ostatnio Dániel Bagi umieścił tę nazwę w nowym kontekście. Analizując źródła średniowieczne, powstałe przede wszystkim w kręgach związanych z Cesarstwem oraz Europą romańską stwierdził, że $S$ (c) lavonia przybrała w nich charakter kulturowy, zastępując określenie Barbaricum. Oznaczała ona kraje pogańskie albo świeżo dopiero schrystianizowane. Ta ciekawa interpretacja godna jest głębszej refleksji ze świadomością, że za tą nazwą kryje się nazwa ludu, zróżnicowanego, ale utrzymującego świadomość wewnętrznego pokrewieństwa, które wyraziło się choćby w późnośredniowiecznych kronikach polskich ${ }^{19}$. Za każdym też razem w trakcie analizy uwzględniać należy kontekst źródłowy.

Uwagi te pozwalają nam przypatrzyć się bliżej geografii ziem zajętych przez Węgrów. Osoby studiujące Kronikę węgiersko-polska od razu zauważą zupełnie inną perspektywę opisu w porównaniu z innymi kronikami węgierskimi. Weźmy dla przykładu Gesta anonimowego notariusza króla Béli, powstałe po 1200 r., czyli mniej więcej w okresie, kiedy zdaniem nowszych badaczy powstała Kronika węgiersko-polska. Tu Węgrzy wychodzą z praojczyzny określonej erudycyjnie jako Scytia, przechodzą przez Ruś i od strony Mukaczewa i Użhorodu rozlewają się po Wielkiej Nizinie Węgierskiej, a potem przekraczają Dunaj wchodząc do Transdanubii ${ }^{20}$. Jest to perspektywa wszystkich pozostałych kronik i rzeczywistości historycznej. Tymczasem przypomnijmy, że nasza Kronika każe Węgrom zająć Sławonię, potem ziemie naddunajskie, międzyrzecze Dunaju i Cisy oraz w końcu tereny na wschód od Cisy. Wyjaśnieniem mogłoby być przyjęcie, że Kronikę skompilowano ze źródeł pisanych i ustnych węgierskich, chorwackich i polskich na sławońskim dworze Kolomana, byłego króla halickiego, dlatego kronikarz spoglądał na Królestwo Węgier od południa. Zarazem rozciągnięcie nazwy Sławonii na całość Węgier, a także nazwanie północnej Sławonii Węgrami, podkreśla jedność gospodarczo-polityczno-geograficzną tych ziem.

Niezależnie od przyczyn tak niecodziennego spojrzenia zwraca uwagę, że charakterystyka zajmowanych terenów w różnych kronikach węgierskich pokrywa się ze sobą i z rzeczywistym obrazem ziem Basenu Karpackiego. Badacze tych kronik od ćwierci tysiąclecia są na tropie zaginionego ich praźródła. Miało ono powstać w drugiej połowie XI albo na początku XII w. i nosić nazwę Gesta Ungarorum, przekaza-

19 D. Bagi, Sclavonia in der Ungarisch-Polnischen Chronik und die angeblichen slawischen Wurzeln des Arpadenreiches, „Chronica“ (wyd. Szeged), t. 12, 2016, s. 57-68; R. Grzesik, Etnogeneza Stowian w polskich kronikach średniowiecznych, „Slavia Antiqua” za 2020 r., w druku (referat wygłoszony na XVI Kongresie Slawistycznym w Belgradzie w sierpniu 2018 r.).

${ }^{20}$ Spośród licznych edycji najbardziej dostępna czytelnikowi polskiemu będzie: Anonimowego notariusza króla Béli Gesta Hungarorum, tłumaczenie A. Kulbicka, K. Pawłowski, G. Wodzinowska-Taklińska, wstęp i przypisy R. Grzesik, Kraków 2006. 
ną w relacji z wyprawy poszukującej węgierskiej praojczyzny przez dominikanina brata Ryszarda ${ }^{21}$. Wydaje się, że ta literacka podstawa w połączeniu z naoczną obserwacją sprawiła, że tereny zajmowane przez Węgrów opisywane są w bardzo podobny sposób ${ }^{22}$. Podkreśla się np. trawiasty, równinny krajobraz, żyzność ziemi, obfitość zwierzyny i ryb. Zwraca uwagę, że kronikarze, zarówno węgiersko-polski, jak i Anonim, odnotowują obecność tam pasterzy. Anonim jednak w kontekście ziem na zachód od Dunaju precyzuje, że byli to pasterze Rzymian, gdyż wypasali swe stada na ich zlecenie. Bliższe spojrzenie na tę problematykę przyniosło zaskakujące rezultaty. Wbrew mojemu wcześniejszemu przekonaniu, że chodzi o resztki ludności rzymskiej, która mogła przetrwać na obszarach panońskich aż do czasów przybycia Węgrów ${ }^{23}$ dokładniejsza analiza wykazała, że w 'pasterzach rzymskich' doszukiwać się można duchowieństwa rzymsko-katolickiego pochodzenia niemieckiego (czy raczej frankijskiego), które uciskało miejscową ludność i uciekło przed Węgrami do Niemiec (czyli Wschodniej Frankonii). Być może na kartach kronik węgierskich zachowała się dawna pamięć Słowian panońskich, usiłujących w drugiej połowie IX w. zrzucić polityczno-kościelną zależność od Wschodnich Franków. Jak wiemy, w przeciwieństwie do Wielkich Moraw to się nie udało ${ }^{24}$. Byłoby to niespodziewane przekształcenie dawnej tradycji historycznej zasymilowanego przez Węgrów tubylczego ludu dla podkreślenia gospodarczo-historycznego charakteru zachodnich ziem Królestwa Węgierskiego.

W powyższych uwagach zajęliśmy się obrazem Chorwacji i Węgier przekazanym przez Kronikę węgiersko-polska. Doszliśmy do wniosku, że obraz Dalmacji, Chorwacji, Sławonii i Węgier, będących zresztą geograficzno-onomastyczną jednością z tym ostatnim regionem, nakreślony został z wykorzystaniem tradycji ustnej oraz pisanej wyjaśniającej początki biskupstwa splickiego, początki władzy węgierskiej nad Chorwacją i Sławonią oraz charakteryzującej ziemie, na których osiedlili się węgierscy przybysze. Do nakreślenia początków Kościoła we Splicie wykorzystano utrzymującą się tradycję o jego założeniu przez św. Pawła Apostoła. Uzasadnieniem

21 Relatio fratris Ricardi (,,De facto Ungarie Magne a fratre Ricardo invento tempore domini Gregorii pape noni”), ed. I. Deér, w: Scriptores rerum Hungaricarum, ed. E. Szentpétery, t. 2, Budapestini 1938, s. 535: "Inventum fuit in Gestis Ungarorum Christianorum". Nazwę tę ostatecznie wprowadził do historiografii B. Hóman, A Szent László-kori Gesta Ungarorum és a XII.-XIII. századi leszármazói, Budapest 1925.

22 Bardziej szczegółowa charakterystyka R. Grzesik, Kronika, s. 63-65.

${ }^{23}$ Choć nigdy w tym kontekście wątków tych nie zanalizowałem - moje rozważania miały charakter źródłoznawczy i poświęcone były rekonstrukcji fragmentów przejętych z zaginionych Gesta, zresztą fraza ,pastores Romanorum” była jednym z argumentów za ich istnieniem - występuje u Anonima, u brata Ryszarda oraz w pochodzącym z 1308 r. Opisie Europy Wschodniej. Bliżej zob. R. Grzesik, Kronika, s. 64-65.

${ }^{24}$ R. Grzesik, Blasi and Pastores Romanorum in the Gesta Hungarorum by an Anonymous Notary, "Res Historica", t. 41, 2016, s. 25-34. Inspiracją służył mi artykuł: Gy. Kristó, Rómaiak és vlachok Nyesztornál és Anonymusnál, w: tegoż., Tanulmányok az Árpád-korról, Budapest 1983, s. 132-190, zwłaszcza s. 160-161. 
władzy Węgrów nad Sławonią stała się kształtująca się tradycja o zabiciu władcy przez poddanych, mająca zapewne wielkomorawskie korzenie. Wreszcie poprowadzenie Węgrów przez Sławonię i nadanie jej północnej części nazwy Węgier podkreśla jedność węgierskiej ekumeny, trudno tu się natomiast doszukiwać śladów funkcjonowania pierwotnej nazwy.

\section{BIBLIOGRAFIA}

\section{Źródla:}

Anonimowego notariusza króla Béli Gesta Hungarorum, tłumaczenie A. Kulbicka, K. Pawłowski, G. Wodzinowska-Taklińska, wstęp i przypisy R. Grzesik, Kraków 2006.

Chronica Hungaro-Polonica, pars 1. (Textus cum varietate lectionum), ed. B. Karácsonyi, Szeged 1969 (Acta Historica Universitatis Szegedensis de Attila József nominatae, t. 26).

Historia Królestwa Stowian czyli Latopis Popa Duklanina, wyd. J. Leśny, Warszawa 1988.

Homza M., Uhorsko-pol’ská kronika. Nedocenený prameň k dejinám strednej Európy, Bratislava 2009.

Ljetopis Popa Dukljanina, [wyd. V. Mošin], Zagreb 1950.

Pismo Święte Stary i Nowy Testament w przekładzie z języków oryginalnych, oprac. zespół pod red. ks. M. Petera i ks. M. Wolniewicza, Poznań 2006.

Relatio fratris Ricardi (,, De facto Ungarie Magne a fratre Ricardo invento tempore domini Gregorii pape noni”), ed. I. Deér, w: Scriptores rerum Hungaricarum, ed. E. Szentpétery, t. 2, Budapestini 1938, s. $529-542$.

Testimonia najdawniejszych dziejów Stowian, seria grecka, z. 3: Pisarze z VII-X wieku, wyd. A. Brzóstkowska, W. Swoboda, Warszawa 1995.

Thomae archidiaconi Spalatensis Historia Salonitanorum atque Spalatinorum pontificum. Archdeacon Thomas of Split, History of the Bishops of Salona and Split, ed. by O. Perić, D. Karbić, M. Matijević Sokol and J. Ross Sweeney, Budapest - New York 2006.

Żywot św. Stefana króla Węgier czyli Kronika węgiersko-polska, tłum. R. Grzesik, Warszawa 2003.

\section{Literatura:}

Bagi D., Sclavonia in der Ungarisch-Polnischen Chronik und die angeblichen slawischen Wurzeln des Arpadenreiches, „Chronica“ (wyd. Szeged), t. 12, 2016, s. 57-68.

Bali T., Slavonski Meandar. Prostor i pojam Slavonije u XIII. stoljeću, Zagreb 2014.

Grzesik R., Blasi and Pastores Romanorum in the Gesta Hungarorum by an Anonymous Notary, "Res Historica", t. 41, 2016, s. 25-34.

Grzesik R., Great Moravia as the Basis of the Central European Medieval Historical Tradition, w: Slovensko a Chorvátsko. Historické paralely a vztahy (do roku 1780). Slovaćka i Hrvatska. Povijesne paralele i veze (do godine 1780.), wyd. M. Homza, J. Lukačka, N. Budak, Bratislava 2013, s. 6671.

Grzesik R., Hungaria - Slavia - Europa Centralis. Studia z dziejów kultury środkowoeuropejskiej we wczesnym średniowieczu, Warszawa 2014.

Grzesik R., Kronika węgiersko-polska. Z dziejów polsko-węgierskich kontaktów kulturalnych w średniowieczu, Poznań 1999.

Grzesik R., rec. z: Martin Homza, Pokus o interpretáciu úlohy kňažnej Adelajdy v Uhorsko-pol’skej kronike, „Historický časopis”, R. 47, 1999, z. 3, s. 357-382; „Studia Źródłoznawcze”, t. 38, 2000, s. $125-127$.

Grzesik R., Sources of a Story About the Murdered Croatian King in the Hungarian-Polish Chronicle, “Povijesni Prilozi”, R. 22, 2003, t. 24, s. 97-104. 
Homza M., Pokus o interpretáciu úlohy kňažnej Adelajdy v Uhorsko-pol’skej kronike, "Historický časopis", t. 47,1999 , z. 3, s. 357-382.

Homza M., Uhorsko-pol'ská kronika. Nedocenený prameň k dejinám strednej Európy, Bratislava 2009.

Hóman B., A Szent László-kori Gesta Ungarorum és a XII.-XIII. századi leszármazói, Budapest 1925.

Klaić N, Povijest Hrvata u ranom srednjem vijeku, Zagreb 1971.

Kristó Gy., Rómaiak és vlachok Nyesztornál és Anonymusnál, w: tegoż., Tanulmányok az Árpád-korról, Budapest 1983, s. 132-190.

Kürbisówna B., Studia nad Kronika wielkopolska, Poznań 1952.

Kurelac M., Toma arhiđakon (Thomas archidiaconus Spalatensis, Toma Splićanin), w: Enciklopedija Jugoslavije, t. 8, Zagreb 1971, s. 348-349.

Nemet D., Smrt hrvatskog kralja Zvonimira - problem, izvori i tumačenja, „Radovi Zavoda za hrvatsku povijest u Zagrebu", vol. 38, 2006, p. 73-91 (w Internecie: http://www.ffzg.unizg.hr/pov/pov2/ files/3zavod/radovi38/nemet38.pdf [dostęp 22 marca 2019 r.]).

Panic I., Ostatnie lata Wielkich Moraw, Katowice 2000.

Veszprémy L., Thomas of Split, w: Encyclopedia of the Medieval Chronicle, wyd. G. Dunphy, Leiden Boston 2010, t. 2, s. 1427-1428. 
